This item was submitted to Loughborough's Research Repository by the author.

Items in Figshare are protected by copyright, with all rights reserved, unless otherwise indicated.

\title{
Migrant encounters with neo-colonial masculinity: producing European sovereignty through emotions
}

PLEASE CITE THE PUBLISHED VERSION

https://doi.org/10.1080/14616742.2018.1489206

\section{PUBLISHER}

(C) Taylor \& Francis (Routledge)

\section{VERSION}

AM (Accepted Manuscript)

\section{PUBLISHER STATEMENT}

This is an Accepted Manuscript of an article published by Taylor \& Francis in International Feminist Journal of Politics on 17 July 2018, available online: http://www.tandfonline.com/10.1080/14616742.2018.1489206.

\section{LICENCE}

CC BY-NC-ND 4.0

\section{REPOSITORY RECORD}

Bilgic, Ali. 2018. "Migrant Encounters with Neo-colonial Masculinity: Producing European Sovereignty Through Emotions". figshare. https://hdl.handle.net/2134/33461. 
Accepted Version, 07.06.2018

\title{
Migrant Encounters with Neo-Colonial Masculinity:
}

\section{Producing European Sovereignty through Emotions}

\begin{abstract}
Ali Bilgic
Lecturer, Department of Politics, History and International Relations, Loughborough University,

Prince Claus Chair in Development and Equity (2017-2019), International Institute of Social Studies, Erasmus University Rotterdam.
\end{abstract}

Email: abilgic@lboro.ac.uk

\section{Acknowledgements}

Different versions of the article was presented at University of Bristol, Queen Mary University of London, International Studies Association's 58th Annual Conference in Baltimore, and European International Studies Association 11th Pan-European Conference in Barcelona. I'd like to thank discussants and audience for their comments and criticisms. I also would like to thank reviewers and editors of the journal for their insightful and constructive engagement with the article. Last, but not least, I am grateful to Terrell Carver for his comments and encouragement when I started the project. 
Accepted Version, 07.06.2018

EU/ropean political community's reaction to irregular migrants is ambivalent. On the one hand, migrants are produced as people to be pitied, rescued and saved. On the other hand, they are feared, despised and left to die. The article looks at this ambivalence from a gender perspective and asks how sovereign masculinities are produced through emotional performances in the politics of migration control and management. It will be argued that emotions such as fear, disgust, and compassion are performed in the biopolitical security governance of irregular migration by producing a 'socially abject' life as its object. This is a life that is to be killed, despised, and saved. Encounters between the irregular migrant and a European border security actor constitute a neo-colonial masculinity. During the moment of the encounter with the other's life, sovereignty is produced through emotional performances of border security actors. The discussion concludes with illustrations of how racialized bodies and lives are produced as objects of fear, disgust and compassion by producing the European neo-colonial masculinity. The article speaks to the debates in the literature of masculinities in global politics, emotions and politics, and critical border studies.

Keywords: masculinity, sovereignty, emotions, neocolonialism, migration 
Accepted Version, 07.06.2018

A painting by Antoine-Jean Gros, Napoleon Visiting the Plague-Stricken at Jaffa, dated 1804, depicts a moment of colonial encounter during the Egyptian campaign of the then victorious Napoleon. His hand reaches out and touches a plague-driven male body. ${ }^{i}$ Portraying Napoleon as similar to the biblical image of Jesus challenges the boundary between a healthy, clean body and a fearsome and disgusted plagued body, which should be spatially separated and, if necessary, killed. Napoleon, soon to be named 'emperor', is selfless and fearless, but also loving, compassionate, and caring towards those who are blessed by his white, victorious and colonial helping touch.

In 2015, a photograph showed a Danish male police officer playing with a young refugee girl.i The photograph was taken right after that of Aylan Kurdi, the body of a three-year-old boy lying on a beach in Turkey, and was contrasted to the latter to convince the global audience that Europe did not address the Syrian refugee 'crisis' in a heartless and violent manner. 'Touching moment', 'hope', and 'love' were recurrent themes of the news surrounding the photo, which quickly found a place in the BBC's 'happy refugees' photo album. iii

(Neo)colonial encounters have always been imbued with emotions, which are expressed through diverse, interrelated, and complex representations of both the colonizer and the colonized. Irrelevant to the question of their genuineness, and going beyond the simplistic argument that 'men also have feelings', the emotional performances of Napoleon and the Danish policeman are political. If, as a Frontex European Union's border control agency-officer said, he is 'a human with feelings' (Pallister-Wilkins, 2015: 61), and if decisions to grant asylum are determined by the emotions 'evoked' in the relevant caseworker (Ticktin, 2005: 365), a political question arises: what do emotions do during the encounter between the representative and protector of the sovereign body politic, and the irregular migrant, 'stranger', and 'deterritorialized body'? This article argues that the encounter between the irregular migrant and the European border security actor is a moment of emotional performance of sovereignty that produces the racialized other-life to be killed, animalized, or saved. These emotional performances of 
Accepted Version, 07.06.2018

sovereignty are constitutive of European neo-colonial masculinity. In this analysis, neo-colonial masculinity refers to a type of masculinity that produces migrating bodies from the Global South as the racialised and gendered 'other' of the Global North through invoking colonial emotions.

By building on and intersecting the literatures of emotions in world politics (Bleiker and Hutchison, 2008; Mercer, 2006 and 2010; Ahmed, 2014; Hutchison, 2016), sovereignty and masculinities (among others, Hooper 2001; Parpart and Zalewski, 2008; Weber, 2016), and critical border studies (Bigo, 1998 and 2002; Vaughan-Williams 2012 and 2015; Karyotis, 2012; Pallister-Wilkins, 2015 and 2017), the article advances the ongoing debates in three ways. Firstly, it discusses the role of emotions in biopolitical border security management from a gender perspective, by shedding theoretical light on how gendered power relations are (re)produced through emotional performances during the daily encounters between the subject (the border security actor) and the object of the emotional performance (irregular migrant). ${ }^{\text {iv }}$ The concept of 'immunitary borders' will offer a perspective for examining the ways in which emotions are enacted as performances of sovereignty. Secondly, it brings the affective dimension to the performativity approach towards sovereignty by exploring what emotions do politically in the production of sovereignty. The goal of the article is not to 'show' fear, disgust and compassion as emotions that can be objectively studied, but how certain bodies and lives are produced as the racialized objects of these emotions by reproducing the sovereign 'Europe' with its neocolonial masculinity. ${ }^{\vee}$ Lastly, following Kabesh (2013), the analysis questions how masculinities are formed in global politics, and underlines the necessity of acknowledging the role of emotions in their performative productions. This is a step towards understanding the formative dynamics of masculinities as living experiences.

The first section focuses on the critical exploration of what emotions do as 'performances' in the politics of irregular migration in Europe. It starts with a conceptual discussion of sovereignty and masculinity from the perspective of performativity based on Weber (1998 and 2016). It is followed by the question of how emotions can be studied as performances of sovereignty and masculinity. Particularly deriving 
Accepted Version, 07.06.2018

from Ahmed (2014), emotions will be conceptualized as performances of sovereignty, whose practices are derived from historical encounters with 'the racialised other'. The third section introduces the concept of 'immunity borders' by deriving from the work of Nick Vaughan-Williams (2015) on 'EUropean' border security practices. The section will be concluded by illustrations of how racialised bodies of irregular migrants are produced as objects of fear, disgust and compassion by the European 'sovereign man' as embodiment of neocolonial masculinity.

\section{Sovereignty, Masculinities and Emotions in Neo-Colonial Encounters}

In the feminist IR literature, the mutually constitutive relationship between man/manhood/masculinity and state/statehood/sovereignty has been critically discussed (Ashley, 1989; Peterson, 1992; Hutchings 2008; Weber, 2016). In general, these studies argue that statecraft and sovereignty as fundamental principles and practices of international relations have been (re)constructed along with the production of a sexualized Western man, manhood, and masculinity. While masculinizing the state and sovereignty legitimizes multiple binaries (including heterosexual/homosexual, inside/outside, state/society, citizen/noncitizen), 'the heterosexual man' as a political subject has also been reproduced as an embodiment of statehood and sovereignty (Weber, 2016). It has been argued that the sovereign body is a masculinized (even hypermasculinized) political institution, which means that its ontology and practices are produced, normalized, and legitimized through masculinization (Maruska, 2010; Stachowitch, 2013).

The conceptualisation of sovereign state as a gendered institution and the dichotomies it entails between inside/outside, state/society, citizen/non-citizen as functions of its sovereignty have long been explored in feminist and queer IR. This analysis adds a less discussed nuance to the ongoing discussion by asking a different question: how is sovereignty reproduced affectively through the daily, bodily encounters between the 'protectors' of the sovereign body and 'dangerous strangers' (see below Ahmed, 2014)? 
Accepted Version, 07.06.2018

To answer this question, the concept of sovereignty should be destabilized. Weber (1998: 49) offers a performativity approach to sovereignty, which fundamentally questions prediscursive ontologies of sovereignty (and state), and suggests, instead, an examination of how sovereignty is reproduced as prediscursive and 'natural'. A performativity approach asks 'what must a state 'do' in order to 'be' sovereign?' enabling the investigation of 'how sovereign practices confer sovereign status onto states' (Weber, 1998: 92). The performances of 'states' through their representatives can be varied, but inevitably involve what these representatives do when they encounter with 'non-citizens' on the borders of the body politic. In Queer International Relations, Weber (2016: 80-91) partly focuses on this question and explores the 'perverted homosexualised' production of migrants 'on the move' in relation to heterosexualised sovereign man/state. Sovereignty is performed during the encounter between the developing (or undevelopable) man who refuses to stay in the Global South by migrating towards the Global North, which is the social space of the 'developed man' (84). And this is where race and colonialism kick in.

Wolfe (2016: 14) argues that 'racialisation represents a response to the crisis occasioned when colonisers are threatened with the requirement to share social space with the colonised'. This response has the character of 'emotive virulence' (13). As will be discussed in the second section, the colonizer's encounters with the colonized were the moments when fear, anxiety, and compassion were enacted through killing, animalizing, and saving respectively. Colonial masculinity as identity was affectively constructed when the colonized was (hyper)feminized, emasculated, or hypermasculinized as an object of the colonizer's affective responses. Contemporary irregular migration from the Global South to 'Europe' occurs within the historical context of previous colonial encounters. The fundamental difference from the colonial period is that the 'unknown' bodies are 'on the move' towards the social space of the former coloniser called Europe. During the moment of the encounter, emotional performances of sovereignty that produce racialized migrants as objects of fear, disgust and compassion innately reflect and reproduce Europe's (neo)colonial masculinity. 
Accepted Version, 07.06.2018

Therefore, the present analysis faces two conceptual issues in relation to the reproduction of sovereignty during encounters with 'strangers', in this case, irregular migrants. Firstly, Butler (1993: 24) argues that performativity 'consists of a reiteration of norms which precede, constrain, and exceed the performer and in that sense cannot be taken as the fabrication of the performer's "will" or "choice"'. When sovereignty is performed, the performances of representatives of the sovereign body reiterate norms, which are derived from a cultural and historical context where sovereignty and masculinity are intertwined. Secondly, if Sara Ahmed (2014: 211) is right when she argues that recognizing someone as a 'stranger' involves an 'affective judgement', the encounter between the border actor and the irregular 'unknown' migrant through which 'the sovereign man' is produced through reiteration of historical and cultural norms of sovereignty (and colonial masculinity) is affective. What do emotions do during such an encounter? How do they produce sovereignty as prediscursive? Sara Ahmed's conceptualizations of emotions and how some bodies are recognised as 'strangers' through 'affective judgements' offer answers.

Ahmed (2014: 7-10) conceptualizes emotions in a way that refuses dichotomies such as 'inside out' (i.e. emotions are inside individuals and communicate with the outside) vs. 'outside in' (i.e. emotions are social and caused by others), 'social' vs. 'psychic', and 'intentional' vs. 'somatic'. Instead, she argues, 'emotions create the very effect of the surfaces and boundaries that allow us to distinguish an inside and an outside in the first place'. For example, the encounter between the child and the bear (2014: 7-8) does not mean that the object of 'fear' (the bear) is inherently fearsome and the subject (the child) is inherently fearful. The encounter is shaped by socially produced knowledge of the child about 'the bear' not specifically that bear-and previous encounters with 'the bear'-not necessarily by that specific child. 'Fear' moves the child's body 'away' from the bear, and, therefore, bodies are resurfaced and boundaries are redrawn between identities. Emotions such as fear, disgust and compassion are not pre- 
Accepted Version, 07.06.2018

discursive or natural, but intersubjectively learned and performed so that some bodies and lives are produced as objects of fear, disgust and compassion.

Ahmed does not dichotomize affect as a bodily 'unintentional' reaction, and emotion as a social, intentional, and conscious reaction, unlike, for example, Massumi (2002). Emotions, she argues, 'involve bodily processes of affecting and being affected' (208). In the afterword of the second edition of the Cultural Politics of Emotion, she explains the choice of emotion as 'an organizing term', as the concept enables her to examine 'not only how we are affected in this way or that way, by this or that, but also how those judgements then hold or become agreed as shared perceptions' (208). She argues that when being affected by something (meaning being moved away or towards that something), we make judgements about things 'in the intensity of bodily responses', and those judgements are enacted (209). Affect and emotion and psychological and intentional are like the yolk and the white (210). They stick together and are enacted.

Ahmed's conceptualisation paves the way for understanding emotions from a performative or practice perspective: judgements are enacted by moving the subject away or towards the object. Margaret Wetherall (2012) conceptualizes 'the affective practice', which is an 'ongoing' and 'in process' social action, but is always constrained by past experiences. Emotions as relational, social, and cultural practices are 'performances' of individuals whose enactments are historically and culturally learned. This does not mean that individuals repeat their past experiences; performativity does not take agency away. 'The performative production of the subject is dependent upon reiteration of the norms and practices that generate the subject; it is this requirement for reiteration that 'enables' the subject to act' (Lloyd, 2005: 97). Through agency, the subject can challenge or reproduce the normative contexts they act in. Whetherell (2012: 118) argues that 'people are likely to be able to mobilize (and be mobilized by) quite wide-ranging and diverse repertoires of affective practices closely linked to context'. Referring to the child-bear encounter, Ahmed also states that the story does not inevitably lead to the same ending (2014: 7). As will 
Accepted Version, 07.06.2018

be discussed below, the concept of immunitary borders allows an analysis of this agency, showing that the border security actor can act in diverse ways by reiterating different norms of sovereignty and colonial masculinity. Whereas this analysis focuses on fear, disgust and compassion, alternative emotional performances cannot be ruled out. The issue, however, is that even if the border security actor enacts a different affective judgement (such as compassion over fear), the subject can still reiterate the neocolonial power relations.

For emotions to 'do' their work, i.e. to resurface bodies and redraw identity boundaries, there should be an encounter, a contact between the bodies affecting each other: 'the attribution of feeling to an object ('I feel afraid because you are fearsome') is an affect of the encounter, which moves the subject away from the object' (Ahmed: 2014: 8). In relation to irregular migration, Ahmed's understanding of 'stranger' is highly relevant. 'Rather than the stranger being anyone we do not recognize, some bodies are recognized as strangers, as bodies out of place'. This is an affective judgement about 'the stranger' who is 'suspicious', 'dangerous', and 'fearsome' (2014: 211). Irregular migrants as 'deterritorialized bodies' in boats without documents, or with forged documents, are unknown 'bodies out of place' for the 'sovereign man', who makes affective judgements in the moment of encounter.

However, Ahmed makes another move that motivates this analysis. She argues that the immediacy of bodily reactions is mediated by histories that come before subjects, and which are at stake in how the very arrival of some bodies is noticeable in the first place' (2014: 212). The question, therefore, is not just the bodily encounter between the border agent and irregular migrant, but why the encounter is affectively performed in a certain way. It will be argued below that the history that mediates the encounters of European border actors and irregular migrants is the colonial history or previous colonial encounters where affective judgements of fear, disgust and compassion were made. The boundary between the European sovereign man (the self) and racialized out-of-space bodies (the other) are reproduced in the Mediterranean, detention centres, and migrant camps through reiteration of colonial affective norms. 
Accepted Version, 07.06.2018

This self-other construction through emotional performances of sovereignty produces 'socially abject objects' through emotional performances of sovereignty. Imogen Tyler (2013: 46) describes social abjection is 'a psychosocial theory, which speaks to how subjects and states are reconstituted as longer histories of violence and struggle that converge within the bordering practices of the political present'. In the production of the state, some populations are continuously imagined, presented, and configured as 'revolting' to the 'hygienic' body politic, which is essentialized as 'good and clean'. Populations that can potentially contaminate the body are put under surveillance and control. Borders between the abjected and the body politic are repeatedly redrawn in urban ghettos, prisons, hospitals, and detention centres. Therefore, the sovereign can govern through fear and anxiety regarding an ever-present risk of being contaminated (Tyler, 2013: 16-22). In particular, she argues that 'disgust functions to affirm the boundaries of the social body (the body politic) through the (actual or symbolic) expulsion of what are collectively agreed to be polluting objects, practices or persons' (2013: 23). Deriving from Ahmed's approach to emotions as boundary-producing performances, Tyler explores the historical and political production of particular populations as 'disgusting objects' in the UK.

Tylor's abjection theory is a psychosocial view at how historically and socially conditioned emotional performances contribute to redrawing boundaries: those between the abjected object and the subject in biopolitical governance. The abjection of people of colour, migrants, women, gays, transgenders, disabled, working class, and low income status populations surely requires an intersectional analysis as well as one that historicizes their abjections as colonial and imperial practices. Tyler successfully integrates and empirically discusses the power politics of emotions in the neoliberal age, and, therefore, paves the way for investigating the neo-colonial dimension of contemporary abjection practices. That said, abjection can be performed before the population becomes present within the territorial borders, and these performances can be conducted on the border, which will be conceptualized below as 'immunitary'. 
Accepted Version, 07.06.2018

If gender is performed (Butler, 1991; Shepherd, 2010), and emotions are performances of 'the self' generating a bordering function that reproduces sovereignty, the resulting questions concern how gendered identities are affectively performed, and what emotions do when they construct gendered identities, subjects, and objects. In order to explore what emotions do, the fear, disgust, and compassion of European border security agents cannot be treated as possessions of these individuals that exist $a$ priori, but they are practised or performed during the encounter with 'the irregular migrant' through respective bodily performances of push-back, containing, or saving: enactments of affective judgements that recognize some bodies as 'strangers' and as performances of sovereignty. Emotions are performed in a historical context where colonial power relations operate. In the following, I will discuss the role of fear, disgust, and compassion in European biopolitical migration management as performances of sovereignty and neo-colonial masculinity by producing the fearsome, disgusting, and helpless 'irregular migrant' as a racialized abjected object.

\section{Neo-Colonial European Sovereignty through Emotional Performances}

The modern conception of border as a geopolitical demarcation line that divides inside and outside has been challenged by critical border studies literature. Instead, contemporary borders, or border practices, have been conceptualised as 'borderscapes' (Parker and Vaughan-Williams, 2012; Brambilla, 2015; a critical endorsement of the concept, see Pallister-Wilkins, 2017b). Borderscapes demystifies the idea of 'border' that separates a political community, which pre-discursively exists, from the outside(r). Along with multiplication and diversification borders (among others, Bigo, 2002; Vaughan-Williams, 2012), borderscapes articulates the border a fluid constructed space, far from being fixed, a space of encountering of multiple actors from both inside and outside of the geopolitical borders. From this perspective, the border is a space of negotiation (Brambilla, 2015), and negation of what is produced as pre-discursive or pre-political: sovereignty. While borderscapes deconstructs and demystifies the concept of border, and 
Accepted Version, 07.06.2018

therefore enables myriad discursive, social, and biopolitical practices of border practices, it also raises the question regarding the sovereign attempts to re-draw the border and re-signify the political community as fixed, pre-discursive, under-threat, and protected.

In other words, sovereignty is performed in the borderscapes (inside and outside of geopolitical borders) through daily encounters between border security actors and 'strangers'. The former aims to re-draw the border that divides inside and outside by producing the latter as its object. As Pallister-Wilkins (2017b: 119) argues, such analysis requires the examination of 'wider socio-political processes beyond the border'. This discussion questions, when a border security actor re-draws the border during an encounter with a 'stranger', what emotions do and how they work. Affective reproduction of migrants as abjected objects is an enactment of sovereignty. Because emotions are social and cultural, as discussed above, the analysis examines an overlooked, albeit fundamental, performance of sovereignty when it is negated by migrants. In these performances, how is the border enacted?

Nick Vaughan-Williams (2015) argues that European border security does not have a generalizable system, but operates with a biopolitical logic that aims to kill and save life concomitantly. Biopolitical border security aims to minimize the risks for 'the trusted traveller's mobility and security through differentiating and controlling those who are not trusted, mainly irregular migrants'. To achieve this aim, private security companies are hired to introduce the latest technology of surveillance, agreements are made with the neighbouring countries to ensure their cooperation with the EU, and land and sea borders are highly militarized. All these security practices reflect a mode of governance that makes life its object to be protected and saved. This is why 'humanitarianism' is not the alternative to European border security, but its fundamental constitutive dimension. For example, saving lives and reducing human suffering as biopolitical border security practices legitimize an increasing militarization of land and borders. However, according to Vaughan-Williams (2015: 45-59), European borders can also be understood as 'thanatopolitical borders', where the sovereign ban, as referenced by Agamben, is unpacked in order to kill in cooper- 
Accepted Version, 07.06.2018

ation with environmental factors (i.e. bad weather and sea conditions). Furthermore, these borders are also 'zoopolitical' (70-85), because they 'animalize' life or reveal 'the animal in the man', in order to make knowable 'the unknown' and, therefore, the risky. He argues that encounters between irregular migrants and border security agents can result in one of the aforementioned practices that is difficult to determine a priori. Rather, multiple logics of biopolitical border security resemble an immune system that protects life, and while protecting it, autoimmunity can sometimes lead to the termination of life itself.

Vaughan-Williams borrows the immunitary borders concept from Roberto Esposito (2008, 2010 and 2011). Esposito's approach surely deserves a detailed discussion; however, in a nutshell and risking its simplification, the immunitarian paradigm's first function is to define the identity of the subject a priori: something to be conserved, preserved, and protected, which is the second function of the paradigm (Esposito, 2011: 144). In other words, when the identity of the subject is defined, it also leads to an identification of the wrong, like a virus that would potentially risk the survival and existence of the subject. As a reactionary mechanism, the immunitas acts when 'the virus' first 'threatens' the body (Esposito, 2011: 144). Operationalizing in the settler-colonial case of Israel, Svirsky (2012: 57) argues that the Israeli immunitas operates, firstly, by 'the separation of bodies from the possibility of opening subjectivities to alteration by concrete others, and (secondly) their distancing from collaborative and shared ways of existence'. The 'double refusal...is the way Zionism immunized itself from intercultural life' (2012: 57-59). Although, as will be discussed below, the European immunitas shares this colonial outlook of pushing 'unwanted' racialized bodies back or confining them in order to pre-empt a possible contamination of the body politic, the very same $a$ priori-defined identity also contains an equally colonial 'essence' called humanitarianism. The a priori-defined identity (for the author, this is the European neo-colonial masculinity) could only survive if the same racialized, gendered, and sexualized 'deterritorialized' life is both pushed away and saved at the same time. 
Accepted Version, 07.06.2018

The importance of Vaughan-Williams' reading of European border security governance for the present analysis is twofold. Firstly, European border security practices do not consist of contending practices reflecting alternative logics of security, but pertain to a single biopolitical border security governance logic. Exclusionary and militarized security practices and 'humanitarian' ones are not opposite mirror images, but complete against each other in order to protect life by differentiating the 'good', 'trusted traveller' from 'the bad' one, who supposedly 'threatens' (like a virus) the health of the body. Fear-based security and compassion-based security are not alternatives to each other. Instead, they are implications of the identity a priori defined as the immunitas. If sovereignty is not pre-discursive, but concerns what states must 'do' to 'be' sovereign, the norms of sovereignty during the encounter with the 'stranger' within a historically produced context are performed through immunitary borders. In other words, border security actors affectively perform 'European sovereignty' by reiterating the norms that a prior define 'Europe' historically and culturally, which brings previous colonial encounters into the discussion.

Secondly, 'encounter' is a key moment in the process of deciding what kind of biopolitical relationship is performed between the irregular migrant and the border security actor (i.e. how the immunitary mechanism works). This actor can be a coastguard officer, soldier, ship captain, bus driver, NGO worker, FRONTEX officer, fisherman and so on. One of the most important consequences of European border security governance is to produce individuals (with official competence or not) as border security agents with the authority to make instant judgements regarding the 'irregular', deterritorialized, 'stranger', life. The judgements are affective and enacted by killing, animalizing, or saving 'the other'. As a result, the sovereign body moves away or towards the 'deterritorialized' life.

Emotional performances of European border security actors are fundamental in (re)constructing European neocolonial masculinity. These emotional performances of sovereignty during the encounters are meditated through historical experiences. Remembering Ahmed, that is why irregular migrants are recognised as 'strangers' and become subjects of fear, disgust and compassion. In the case of Indian and 
Accepted Version, 07.06.2018

British masculinities during the colonial period, Kabesh (2013) powerfully argues that emotions were psychosocial phenomena through which colonial masculinities encountered their 'other'; thus, they could not be ignored as 'irrational' nor could be reduced to apolitical and asocial privatized psychology. Even though this analysis endorses the argument of Kabesh, it differs in two fundamental ways. Firstly, in addition to emotions that move the subject away from the object, there were also emotions, such as compassion and love, which moved the colonizer towards the colonized in the practices of civilizing, developing, or helping (Lester and Dussart, 2014: 6-9). These colonial affective judgements are now performed in the form of humanitarianism (see below). Secondly, masculinities do not simply have emotions; instead, emotional performances are productive of sovereign masculinities. In the case of European neocolonial masculinity, border security actors' emotional performances are reiterations of norms that are culturally and historically produced. In other words, they emotionally re-perform a European sovereign masculinity in encounters with 'the other' by reproducing a neo-colonial gendered and racialized power hierarchy.

Next, I will show how sovereignty is affectively performed with illustrations from the European border security governance. I will focus on the experiences of migrants who are reproduced as fearsome, disgusting objects, or those who 'deserved' saving by the European sovereignty. The reason why this method is chosen is to illustrate the 'affective economy' of the biopolitical migration security governance. According to Ahmed (2014: 15 and 64), the affective economy produces some subjects with 'emotional capital' as feeling subjects, whose power is accumulated as the affects circulate; and others as the objects of affects such as 'disgusting', 'fearsome', and 'pitiful'. This is a power relation which, in the present case, is embodied as neocolonial sovereign masculinity. Illustrations that concentrate on the 'objects' of affective economy show that these affects are in circulation.

Fear: Kill 
Accepted Version, 07.06.2018

It has been widely discussed that fear is one of the driving forces of the migration-security nexus in Europe (Bigo, 2002 and 1998; Dillon, 2004; Huysmans, 2006). It is also the emotion that reconstructs the EU's citizen-warrior masculinity (Hooper, 2001: 98). Fear, its associated feelings such as anxiety and uneasiness (Bigo, 2002) towards 'the other', and the urge to eliminate the risks and potential threats to self-preservation are highly associated with the citizen-warrior masculinity. This masculinity produces mainly male (albeit not exclusively) bodies and subjects as the militarized, aggressive, and proactive protectors/citizens of the community against risks and threats inside the spatial borders. The fear that once the political body inside the immunitary borders is penetrated by 'the other', its existence would be in jeopardy, is the overarching feeling of this type of masculinity. When the feeling of fear and its affective reactions are expressed, communicated, and represented, it becomes an emotional performance that redraws the borders between the self-life that needs protection and the other-life that can be killed.

European border security actors, from FRONTEX officers to ship captains, can feel fear and anxiety not because it is natural to feel it, but because European 'sovereign man' in relation to 'irregular migrants' has been (re)produced, based on the historical colonial encounters with 'the other'. Bhabha (1998) and Fischer-Tiné (2016) study multiple encounters between the colonial man and the colonized where the latter engendered excessive fear, anxiety, and panic in the former. Anxiety in relation to the 'unknown' non-white, fear of miscegenation with a 'lower race', and panic about being 'outnumbered' by the other resulted in aggressiveness towards the colonized in order to protect the white political body.

In November 2015, a video of a Greek coast guard was released. The video shows a rubber boat carrying irregular migrants floating towards the coastguard boat. As the boat approaches and migrants try to hold onto the coastguard boat, a crewman carrying a large pool appears and starts pushing the boat away. His impact pierces the rubber and the boat starts sinking. The passengers are saved by the group that is performing the recording. ${ }^{\text {vi }}$ Another violent encounter between European border agents and irregular migrants was described to Amnesty International by a migrant: 'Instead of trying to rescue us they were 
Accepted Version, 07.06.2018

taking photos, instead of rescuing us they were taking photos... and while we were trying to get on the ship they hit me... They slapped me twice. They hit me! This was the rescue [by the Greek Coastguard]' (Squire et al. 2017: 65). Recently, Amnesty International released a report about how violently Hungarian police and migration forces pushed back irregular migrants to Serbia. vii

The illustrations above show how the European sovereignty is produced through the emotional performance of fear. The affective judgement about 'dangerous stranger' is enacted (push-back) and, therefore, moves the body away from the object of fear and is eventually left to die. By pushing the boat away, the coast guard 'secured' the European sovereign body. Therefore, he reiterates the norm of sovereign practice. Contextualized in previous historical experiences during their encounters with the 'nonwhite', deterritorialized, 'unknown' bodies, European border security actors perform fear by pushing back irregular migrant boats and letting their occupants die in bad weather and sea conditions. Therefore, the border is redrawn between the life and 'the other' life that can be killed in the neo-colonial context. The citizen-warrior masculinity of the EU produces and is produced by the momentary affective reaction of the individual to perform fear.

Neo-colonial masculinity's other constitutive part is bourgeois-rational masculinity (borrowed from Hooper, 2001: 97). The bourgeois-rational sovereign 'man' is different from the citizen-warrior in the sense that 'he' does not valorize violence and aggressiveness, but praises rationality and liberal values. This sovereign man is presented as compassionate towards those are 'in need' of help, protection, and guidance. However, the bourgeois-rational man is no less effective in producing the other as a racialized abjected object. This will be discussed in two emotional performances in which disgust and compassion are performed in the biopolitical management of border security.

\section{Disgust: Animalize}


Accepted Version, 07.06.2018

The second emotional performance concerns the animalization of irregular migrants through producing them as a 'disgusting' other. Like fear, disgust is a colonial emotion. In the colonial context, disgust was generally associated with 'the unclean' and non-hygienic (MacFarlane, 2008), but also with those who were considered physically 'ugly' in the colonial imagination, such as fat (Forth, 2012). It was the 'emotion of superiority' of the colonizer over 'the other', who was incarcerated, put under control and observation, and made 'known' (Schwarz, 2010). Based on previous encounters, neocolonial European bourgeois-rational masculinity is performed through disgust targeting the irregular migrant. Animalization of the irregular migrant through rendering it a 'disgusting' object is a bordering technology of biopolitical border management. Although it does not let it die, it does not allow the irregular migrant to pass the edge that separates the hygienic 'white' self and the 'disgusting', animalized, other. This performance of disgust is not arbitrary, but builds up from the colonial practice that produces a certain colonized object, successfully described by Frantz Fanon: an animalized black man. The 'white' self cannot simply 'kill' the colonized other, as 'he' needs 'the other' to be.

In September 2015, a video recorded by an Austrian woman showed the world a scene from a camp in Rozske, Hungary, where irregular migrants were thrown food by the camp officers, whose bodies were fully covered and protected with plastic gloves and sanitary masks; their skin would not be exposed to irregular migrants' bodies. Human Rights Watch's emergency director stated that irregular migrants were held like 'cattle in pens'. viii In April 2016, an irregular migrant from Pakistan, who wanted to apply for asylum, stated that 'only Pakistani and Bangladeshi people are being targeted. I think Greek officials hate us. They are treating Pakistani people like animals'. ${ }^{\text {x }}$ A Syrian, who arrived in Germany without documents but applied for asylum, explicitly stated how we was made to feel and how this feeling of 'being like animals' led to the feeling enslavement: 'At a certain point, some people start to think to go back. We felt ourselves as animals, not human beings. The security staff [here], doesn't allow you to go out or come inside...They make you feel as if: 'you are my slave, the moment you disagree with me, I will throw 
Accepted Version, 07.06.2018

you out' (Squire et al. 2017: 78). Incarceration of irregular migrants is recognized as a defense of Europe. When he was asked why the conditions in detention camps in Italy were harsh and limited, the manager of the camp responded by invoking the militarised discourse of protecting 'Europe': 'If they know that they'll go straight to a shelter where people will help them get where they want to go, the flow would be much greater. We are the frontier of Europe'. ${ }^{x}$

Surely, migrants' affective 'othering' is not limited to camps. Emotional performances of the 'sovereign man' are extended to the societies by making migrants feel like 'animals'. A migrant from Afghanistan told Amnesty International (2016: 16) that 'I have spent 38 days in the camp, I will get to cross the border in 12 days. [...] Yesterday I went to Horgoš, the shopkeeper said I have no permission to be there. The hairdresser refused to cut my hair. The police and people look me down as if we were not human' (Amnesty. 2016: 16). In June 2015, public bus drivers in Milan made it to the news when they refused to take dark-skin migrants on the bus and the company defended his act as 'not racism' but a 'sanitary measure' (Browne, 2015).

Reproducing irregular migrants as objects of disgust (or sources of disease) is the second emotional performance of 'the sovereign man'. Whether a detention camp officer or a bus driver, the European 'sovereign man' was moved away from the racialized body who was produced and circulated socially as 'disgusting'. The aforementioned accounts are not rare, neither on European territories nor in the regions where the EU has outsourced irregular migration control. Being held in overcrowded rooms with limited facilities, forcing migrants to sleep in their own urine, restricting possibilities of having a shower, being thrown food, and being beaten 'like animals' are boundary-producing emotional performances of disgust that are practiced during the encounter between the irregular migrant and the European border security actor. The latter is reproduced as the embodiment of the clean and good 'hygienic' self, whereas the former is produced through a performance of disgust as an abjected object of the liberal-rational sover- 
Accepted Version, 07.06.2018

eign subject. Unlike the citizen-warrior, this sovereign man values life and protects it by animalizing the other-life, therefore reproducing his racialized and gendered power over the 'inferior'.

\section{Compassion: Save}

The third dimension or productive performance of the EU's bourgeois-rational masculinity is about compassion towards the 'irregular' life as a humanitarian practice. One of the fundamental practices of European border security management is to reduce human suffering and deaths during the irregular crossings. The European Commission, as the pioneer of this practice, repeatedly expresses the necessity of a humanitarian border management that takes migrant life and well-being into account when formulating migration control policies. This 'migrant-centred' approach is underlined particularly in the 1999 Tampere Program on the Area of Freedom, Security and Justice, and then in the 2011 Global Approach to Migration and Mobility. ${ }^{\mathrm{xi}}$ FRONTEX's main objective is also defined as coordinating the 'search and rescue' (SAR) operations of the EU member states. Some literature considers the discrepancies between the humanitarian approach and continuing deaths and rights violations as the gap between discourse and rhetoric (for example, Mezzadra and Neilson, 2013: 171). In contrast, humanitarian border management is part of the biopolitical approach to migration control (Pollister-Wilkins, 2015 and 2017) that aims to 'save' life, and I add that it is an emotional performance of its sovereign neo-colonial masculinity.

Since the normalization and legitimization of colonialism as 'the white man's burden' to work for the well-being of the colonized, humanitarianism as the betterment and saving of the 'lower life' has been an ideological undercurrent of the humanitarianism of the West (Ticktin, 2011; Fassin, 2012). This humanitarianism has been reproduced by humanitarian interventions, humanitarian aid, and multiple renditions of human security that keep underlining the responsibility of the 'white man' towards fellow human beings sharing a common humanity (Fassin and Pandolfi, 2010). Some bodies are not produced as 
Accepted Version, 07.06.2018

'dangerous strangers', but strangers who 'deserve' the compassion of the neocolonial masculinity as performances of sovereignty.

In the affective economy, the circulation of affect increases its 'capital value' and produces the subjects and objects of emotions (Ahmed, 2014: 45). Images are extremely important tools in these circulations. The images and videos in the 'rescue stories' in the Mediterranean that are circulated by international media outlets overwhelmingly show exhausted, starving, and terrified 'black' bodies and 'white' saviours (coast guards or NGO workers) who reach out to save the latter. Unlike the previous emotional performances, the 'sovereign man' moves towards the other body. As these images are circulated repeatedly, the racialised bodies are recognized as 'strangers' who are objects of compassion of 'Europe'. The images are accompanied by stories that reproduce Europe as the ultimate destination to be desired by the racialised other:

"In a few days you will be in Italy, in Europe. Libya is over," each group was told in English or French, often drawing applause and cheers of joy from those who were not too exhausted, seasick or traumatized from their journey (Scherer, 2017).

When the encounter of the Danish police officer and the refugee girl (see Introduction) is contextualized within previous historical encounters between the racialized 'white' and 'non-white' bodies, his compassionate and loving performance can be articulated not as an exception, but as a daily practice of colonial masculinity. In the affective economy of neocolonial encounters, 'life to be saved' is a neo-colonial gendered concept that produces the subject, a man, who is compassionate, loving and caring. The abjection of irregular migrant does not stem from fear and disgust, but the compassion of the European border security actor, who decides those worthy of the other-life to receive 'his' compassion. This renders compassion and care towards irregular migrants inextricably neo-colonial and biopolitical as performances of the European sovereign man. 
During the process of (re)producing the compassionate European 'sovereign man', three further points should be underlined. Firstly, as Ahmed (2014: 25) argues, emotions 'slide', meaning they move between objects and they do not always have the same enactment. The images of 'rescue operations' are often used by racist, xenophobic, and anti-migrant media as a 'show' of the white man's 'generosity'. For example, the UK's Daily Mail as a direct representative of this type of media outlets praises the 'British' sailors who saved 15,000 'migrants' and added the words of a 'rescued migrant' to the images: 'I was granted a new life. I thank them with all my heart and I thank Britain for providing me with everything I need in life.' (Brown, 2017). Secondly, the abjection of the irregular migrants' lives is not limited to the ambivalence and uncertainty surrounding their bodies about whether they would be a recipient of compassion. Following the shooting of the photo with the Danish policeman, the young migrant girl disappears into the collective body of irregular migrants. There is a possibility that she did apply for asylum, maybe with her family members. What the emotional performance of compassion hides is the abjection that she could be subjected to after being allowed to apply for asylum as an internal object of disgust (Tyler, 2013). xii Lastly, Italy has recently asked all NGOs that are conducting rescue operations in the Mediterranean to sign a 'a code of conduct' that 'force them to allow police officers on board and return immediately to port, rather than transferring migrants to other ships' . $^{\text {xii }}$ Reacted to by NGOs, the fate of the proposal is yet to be seen, but it is necessary to note that not all 'Europeans' are 'allowed' to rescue, as the performances of sovereignty is limited to the representatives states.

\section{Conclusion}

Sovereignty and masculinities in global politics are emotionally performed. Fear, hate, disgust, love or compassion are emotional performances that are embedded in social and political relations where gender and gendering play important roles. Rather than a dichotomy between rationality and emotionality where the latter is associated with either femininities or subordinated masculinities, understanding what emotions do in the production of masculinities, both subordinated and hegemonic, is a step towards de- 
Accepted Version, 07.06.2018

stabilizing power relations. By showing how fear, disgust and compassion are performed, I hope to pave the way for questioning the EU's neo-colonial masculinity and how it is produced through performative emotional practices of European border security actors. Fearing, disgusting, and loving racialized, gendered, sexualized, and commodified bodies and lives are biopolitical technologies through which the EU's neoliberal sovereign 'man' protects the hygienic self, bordering against the abjected objects.

The ambivalence that surrounds who, under what conditions, what type of encounter (let it die, animalize, save) as a performance of which emotion (fear, disgust, compassion) is the technology of biopolitical border security practice. The EU's neo-colonial masculinity is undergird and legitimized by this ambivalence. The irregular migrant does not and cannot know prior to the encounter with a European border security actor whether she will be let to die, be animalized or saved. This is a form of neo-colonial power over the racialized, gendered, sexualized, disabled other-life in the body of the irregular migrant. In conclusion, this ambivalence enables the EU to reproduce its identity both as the welcoming, loving, hospitable sovereign and as the proactive, aggressive, strong sovereign that secures the hygienic body by producing spatial borders at the sea and detention centers. Immunitary borders are drawn and redrawn through sovereign performances of fear, disgust, and compassion.

\section{References}

Ahmed S. 2014. The Cultural Politics of Emotion. Oxon: Routledge (2nd edition).

Amnesty International . 2016. Stranded Hope: Hungary's Sustained Attack on the Rights of Refugees and Migrants. Available at https://www.amnesty.org/en/documents/eur27/4864/2016/en/ (Accessed 28/08/2017) 
Accepted Version, 07.06.2018

Ashley, R. K. 1989. "Living on Border Lines: Man, Poststructuralism, and War." In International/Intertextual Relations: Postmodern Readings of World Politics, edited by J. Der Derian and M.J. Shapiro, 259-321, Massachusetts: Lexington.

Bigo, D. 1998. "Frontiers and security in the European Union: the illusion of migration control." In The Frontiers of Europe, edited by Malcolm Anderson and Eberhard Bort, 148-164, London: Ashgate.

Bigo, D. 2002. "Security and Immigration: Towards a Critique of the Governmentality of Unease." Alternatives 27 (Special Issue), 63-92. doi: 10.1177/03043754020270S105

Bhabha, H. 1996. "The other question: Difference, discrimination, and the discourse of colonialism." In Black British Cultural Studies: A Reader, edited by, Houston A. Baker, Manthia Diawara, and Ruth Lindeborg, 87-106, California: University of Chicago Press.

Brambilla, C. 2015. "Exploring the Critical Potential of the Borderscapes Concept." Geopolitics 20(1): 1434. doi: $10.1080 / 14650045.2014 .884561$

Brown, L. 2017. "British sailors have rescued 15,000 migrants." The Daily Mail, January 2. Available at http://www.dailymail.co.uk/news/article-4080806/British-sailors-rescued-15-000-migrants-

Mediterranean-18-month-mission-destroyed-110-boats-used-smuggling-gangs.html $\quad$ (Accessed 23/08/2017)

Browne, P. 2015. "Bus drivers 'not racist' for refusing immigrants". The Local. 18 June. Available at https://www.thelocal.it/20150618/milan-bus-drivers-refuse-to-transport-migrants $\quad$ (Accessed 23/08/2017)

Butler, J. (1993). Bodies that Matter: The Discursive Limits of 'Sex'. London: Routledge.

Dillon, M. 2004. "The security of governance." In Global Governmentality: Governing International Spaces, edited by Wendy Larner and William Walters, 76-94, London: Routledge. 
Accepted Version, 07.06.2018

Esposito, R. 2008. Bios: Biopolitics and Philosophy, translated by T. Campbell, Minneapolis: University of Minnesota Press.

Esposito, R. 2010. Communitas: The Origin and Destiny of Community, translated by T. Campbell, Stanford: Stanford University Press.

Esposito, R. 2011. Immunitas: The Protection and Negation of Life, translated by By Zakiya Hanafi, London: Polity.

Fassin, D. 2011. "Policing Borders, Producing Boundaries. The Governmentality of Immigration in Dark Times." Annual Review of Anthropology 40 (October): 213-226. doi: 10.1146/annurev-anthro-081309145847

Fassin, D. 2012. Humanitarian Reason: A Moral History of the Present. Berkeley, CA: University of California Press.

Fassin, D. and M. Pandolfi (eds.). 2010. Contemporary States of Emergency: The Politics of Military and Humanitarian Interventions. New York: Zone Books.

Fischer-Tiné, H. (Ed.). 2016. Anxieties, Fear and Panic in Colonial Settings: Empires on the Verge of a Nervous Breakdown. Hampshire: Palgrave Macmillan.

Forth, C. E. 2012. "Fat, Desire and Disgust in the Colonial Imagination." History Workshop Journal 73(1), 211-239).

Hooper, C. 2001. Manly States: Masculinities, International Relations and Gender Politics. New York, Colombia University Press.

Hutchings, K. 2008. "Cognitive Short Cuts" in Rethinking the 'Man' Question: Sex, Gender and Violence in International Relations, edited by Jane Parpart and Marysia Zalewski, London: Zed Books. 
Accepted Version, 07.06.2018

Hutchison, E. 2016. Affective Communities in World Politics: Collective Emotions After Trauma, Cambridge: Cambridge University Press.

Huysmans, J. 2006. The politics of insecurity: fear, migration and asylum in the EU. London: Routledge.

Kabesh, A. T. 2016. Postcolonial Masculinities: Emotions, Histories and Ethics. London: Routledge.

Karyotis, G. 2012. "Securitization of Migration in Greece: Process, Motives, and Implications." International Political Sociology 6(4), 390-408. doi: 10.1111/ips.12002

Lester, A. and Dussart, F. 2014. Colonization and the origins of humanitarian governance: protecting aborigines across the nineteenth-century British Empire. Cambridge: Cambridge University Press.

Lloyd, M. 2005. Beyond identity politics: Feminism, power and politics. London: Sage.

Maruska, J.H. 2010. "When are states hypermasculine?." In Gender and International Security: Feminist Perspectives, edited by Laura Sjoberg, 235-255, Oxon: Routledge.

Massumi, B. 2002. Parables for the Virtual: Movements, Affect, Sensation. Durham, NC: Duke University Press.

McFarlane, C. 2008. "Governing the contaminated city: Infrastructure and sanitation in colonial and post-colonial Bombay." International Journal of Urban and Regional Research 32(2), 415-435. doi: 10.1111/j.1468-2427.2008.00793.x

Mezzadra, S. and B. Neilson. 2013. Border as Method, or, the Multiplication of Labor. Durham, NC: Duke University Press.

Pallister-Wilkins, P. 2015. "The Humanitarian Politics of European Border Policing: Frontex and Border Police in Evros." International Political Sociology 9: 53-69. doi: 10.1111/ips.12076 
Accepted Version, 07.06.2018

Pallister-Wilkins, P. 2017a. "Humanitarian Borderwork." In Border Politics: Defining Spaces of Governance and Forms of Transgression, edited by Cengiz Gunay and Nina Witjes, 84-103, Cham: Springer.

Pallister-Wilkins, P. 2017b. "Médecins Avec Frontières and the Making of a Humanitarian Borderscape." Environment and Planning D: Society \& Space 36(1): 114-138. doi: 10.1177/0263775817740588

Parker, N. and Vaughan-Williams, V. 2012. “Critical Border Studies: Broadening and Deepening the 'Lines in the Sand' Agenda." Geopolitics 17(4): 727-733. doi: abs/10.1080/14650045.2012.706111

Peterson, S. 1990. 'Whose rights? A Critique of the "Givens" in Human Rights Discourse', Alternatives: Global, Local, Political 15(3) 183-206. doi: 10.1177/030437549001500304

Scherer, S. 2017. "In busy day for rescues at sea, migrants cheer when told 'Libya is over'". Reuters. Available at http://www.reuters.com/article/us-europe-migrants-rescue-idUSKCN18E2MW (Accessed 23/08/2017)

Schwarz, T. 2010. "Colonial disgust: the colonial master's emotion of superiority'." In German Colonialism, Visual Culture, and Modern Memory, edited by Volker Langbehn, 182-196, London: Routledge.

Squire, V. 2014. "Desert 'trash': Posthumanism, border struggles, and humanitarian politics." Political Geography 39, 11-21. doi: 10.1016/j.polgeo.2013.12.003

Squire, V., Dimitriadi, A., Perkowski, N., Pisani, M., Stevens, D., Vaughan Williams N. 2017. Crossing the Mediterranean Sea by Boat: Mapping and Documenting Migratory Journeys and Experiences, Final Project Report, www.warwick.ac.uk/crossingthemed

Stachowitsch, S. 2013. "Military privatization and the remasculinization of the state: making the link between the outsourcing of military security and gendered state transformations." International Relations 27(1), 74-94. doi: 10.1177/0047117812470574 
Accepted Version, 07.06.2018

Svirsky, M. 2012. "The Cultural Politics of Exception." In Agamben and Colonialism, edited by Marcelo Svirsky and Simone Bignall, Edinburgh: Edinburgh University Press.

Ticktin, M. I. 2005. "Policing and humanitarianism in France: immigration and the turn to law as state of exception." Interventions 7(3), 346-368. doi: 10.1080/13698010500268148

Ticktin, M. I. 2011. Casualties of care: Immigration and the politics of humanitarianism in France. California: University of California Press.

Tyler, I. 2013. Revolting Subjects: Social Abjection and Resistance in Neoliberal Britain. London: Zed.

Vaughan-Williams, N. 2012. Border Politics: The Limits of Sovereign Power. Edinburgh: Edinburgh University Press.

Vaughan-Williams, N. 2015. Europe's Border Crisis: Biopolitical Security and Beyond. Oxford: Oxford University Press.

Weber, C. 1998. “Performative states.” Millennium 27 (1): 77-95. doi: 10.1177/03058298980270011101

Weber, C. 2016. Queer International Relations. Oxford: Oxford University Press.

Wetherell, M. 2012. Affect and Emotion: A New Social Science Understanding. London: Sage.

Wolfe, P. 2016. Traces of history: Elementary structures of race. London: Verso Books.

Zalewski, M. and J. Parpart, (Eds.). 1998. The Man Question in International Relations. Oxford: Westview.

\footnotetext{
${ }^{i}$ See, https://en.wikipedia.org/wiki/Bonaparte_Visiting_the_Plague_Victims_of_Jaffa

ii See, http://www.independent.co.uk/news/world/europe/photographer-who-captured-moving-photographs-of-apolice-officer-playing-with-a-refugee-child-10502019.html

iii See, http://www.bbc.co.uk/news/blogs-trending-34257055

iv The concept of 'irregular migrant' refers to migrants who travel without documents or with forged documents, some of whom might apply for asylum upon their arrival to the receiving country. Because of their 'unknown' characteristics and racialised production of their bodies, irregular migrants are 'strangers' or 'deterritorialised bodies' as constructed threats to 'the European sovereign man' and its neocolonial masculine identity.
} 
${ }^{\mathrm{v}}$ It is possible to link emotional performances of border actors with wider discursive context of fear and hate in contemporary European politics. The wider context that I chose to focus on in the article, however, is the colonial context, which is often neglected in Critical Security Studies literature on migration.

vi The video is available onhttp://www.independent.co.uk/news/world/europe/video-sees-greek-coastguard-accusedof-deliberately-trying-to-sink-refugee-boats-a6743971.html (Accessed 04.08. 2017)

vii The report is available at https://www.amnesty.org.uk/files/stranded_hope_eur2748642016.pdf

viii http://www.bbc.com/news/world-europe-34216883

ix http://www.ibtimes.co.uk/refugee-crisis-pakistani-migrants-greece-treated-like-animals-1554124

$x$ Available at https://www.hrw.org/news/2017/07/31/spain-migrants-held-poor-conditions

xi http://eur-lex.europa.eu/legal-content/en/ALL/?uri=celex\%3A52011DC0743

xii Didier Fassin (2011) also discusses the 'humanitarian' logic that categorizes migrants who are produced as the deserving humanitarian help or those who do not.

xiii http://www.independent.co.uk/news/world/europe/refugee-crisis-ngo-rescue-ships-mediterranean-libyasmugglers-italy-code-of-conduct-threatens-lives-a7842966.html 